\title{
Spatial Distribution of Ammonium and Calcium in Optimally Fertilized Pine Plantation Soils
}

\author{
Ivan Edwards, Andrew Gillespie,* Jennifer Chen, Kurt Johnsen, and Ronald Turco
}

\begin{abstract}
Commercial timber production is increasingly reliant on long-term fertilization to maximize stand productivity, yet we do not understand the extent to which this practice homogenizes soil properties. The effects of $16 \mathrm{yr}$ of optimal fertilization and optimal fertilization with irrigation (fertigation) on forest floor depth, $\mathrm{pH}$, total organic carbon (TOC) and total nitrogen (TN) content, and concentrations of potentially plant available $\mathrm{NH}_{4}^{+}, \mathrm{Ca}^{2+}, \mathrm{Mg}^{2+}$, and $\mathrm{Al}^{3+}$ in the fine root zone of monoculture loblolly pine (Pinus taeda L.) stands in North Carolina were examined. Generally, optimal fertilization significantly increased forest floor depth and the concentrations of potentially plant available $\mathrm{NH}_{4}^{+}, \mathrm{Ca}^{2+}$, and $\mathrm{Mg}^{2+}$. No significant effects on $\mathrm{TOC}$ or $\mathrm{TN}$ were observed. However, differences were observed between optimally fertilized and fertigated treatments. Specifically, fertilization alone tended to retain more $\mathrm{Ca}^{2+}$ and $\mathrm{Mg}^{2+}$ in the root zone and to increase pH more than fertigation. Semivariogram analysis indicated optimal fertilization generally lead to a significant increase in the effective spatial autocorrelation ranges of $\mathrm{NH}_{4}^{+}$and $\mathrm{Ca}^{2+}$ at the end of the growing season, from approximately $25 \mathrm{~m}$ in controls to more than $100 \mathrm{~m}$. However, optimally fertilized and fertigated plots differed in terms of their $\mathrm{NH}_{4}^{+}$and $\mathrm{Ca}^{2+}$ spatial autocorrelation ranges, with the ranges in fertigated plots being 1.5 - to 2 -fold greater. $A$ comparison of kriged maps of $\mathrm{NH}_{4}^{+}$and $\mathrm{Ca}^{2+}$ availability in fall 2000 and spring 2001 suggested that the spatial distribution of $\mathrm{Ca}^{2+}$, which has not been added to these soils for $6 \mathrm{yr}$, was stable, whereas the heterogeneity of $\mathrm{NH}_{4}^{+}$distribution increased post fertilization.
\end{abstract}

OBLOLLY PINE is grown commercially throughout the 1 Southeastern USA, and is considered the most important softwood species of the region (Schultz, 1997). On the sandy soils of the North Carolina Sandhills and Piedmont regions, $\mathrm{N}$ and water availability are the biggest constraints to loblolly pine growth (Schultz, 1997). Recently, it has been demonstrated that application of an intensive management system and optimal nutrition can significantly increase the productivity of loblolly pine monocultures on these N-poor and xeric soils (Albaugh et al., 1998). Optimal nutrition involves adding a balanced mix of limiting nutrients annually at a rate determined through foliar analysis to be optimal for immediate plant growth needs (Albaugh et al., 1998; Bergh et al., 1999). As sandy soils represent approxi-

I. Edwards and R. Turco, Dep. of Agronomy, Purdue Univ., Lilly Hall of Life Sciences, 915 West State Street, West Lafayette, IN 47907-2054; A. Gillespie and J. Chen, Dep. of Forestry and Natural Resources, Pfendler Hall, 715 West State St., West Lafayette IN $47907-$ 2061; K. Johnsen, USDA Forest Service Southern Research Station, Forestry Sciences Lab., P.O. Box 12254, 3041 East Cornwallis Rd., Research Triangle Park, NC 27709. Received 18 Mar. 2004. *Corresponding author (andyg@purdue.edu).

Published in Soil Sci. Soc. Am. J. 69:1813-1821 (2005).

Forest, Range \& Wildland Soils

doi:10.2136/sssaj2004.0112

(c) Soil Science Society of America

677 S. Segoe Rd., Madison, WI 53711 USA mately 7 to $10 \%$ of the area available for loblolly pine production (Schultz, 1997), optimum nutrition may become strategically important to meet global demand for loblolly derived forest products (Albaugh et al., 1998).

Natural forest soils are rarely homogenous, and variations in microtopography, organic matter content, particle-size distribution, and hydrologic properties across the soil create a patchy mosaic of different nutrient-rich and nutrient-poor areas. Soil nutrient distributions have been found to vary significantly both between and within forest soils (Zinke, 1962; Trangmar et al., 1987; Robertson et al., 1988; Gallardo, 2003). This patchy distribution of nutrients is believed to be the main cause of growth variation between individual trees in most monoculture stands (Schultz, 1997). Variations in nutrient distribution within a stand are therefore of particular importance in commercial forestry as they may affect the uniformity of stand development and hence final productivity. A more homogeneous distribution of water and nutrients may allow for increased production of loblolly pine and other intensively managed species (Bergh et al., 1999). Although intensive management strategies such as optimal nutrition have been shown to successfully boost productivity, there is little knowledge of the impact of such management options on nutrient distributions. Such knowledge will likely become more important as industry moves to maximize production through the introduction of more intensive agricultural-type management systems (Bradshaw and Strauss, 2000) and genetically modified clonal tree stock (McKeand et al., 1997).

In this study, we evaluated the effect of long-term optimal nutrition on the spatial distribution of selected soil chemical properties in soils of experimental loblolly pine plantations in southern North Carolina. The primary objective of this study was to determine the extent to which optimal fertilization and optimal fertilization with irrigation (fertigation) altered the spatial distribution of growth-limiting nutrients at the plot scale. Our approach was to fit semivariogram models to soil data and determine the effective range of spatial dependence. Spatial dependence of soil properties defines how soil samples vary from one another based on the relative distance between sampled areas (Rossi et al., 1991). The smaller the effective range, the more heterogeneous the spatial distribution. Soil samples were taken at the end of the growth season in October 2000, and again in April 2001.

\section{MATERIALS AND METHODS}

\section{Site Description}

This study was conducted at the Southeastern Tree Research and Education Site (SETRES) - a loblolly pine planta-

Abbreviations: SETRES, Southeastern Tree Research and Education Site; TN, total nitrogen; TOC, total organic carbon. 
tion located in the sandhills region of North Carolina, in Scotland County. The area is flat, infertile, and excessively drained, and the dominant soil, of the Wakulla series is a siliceous, thermic Psammentic Hapludult previously planted to longleaf pine (Pinus palustris Mill.). Reported bulk density of the A horizon (0- to 7.5-cm depth) ranges from 1.20 to $1.22 \mathrm{~g} \mathrm{~cm}^{-3}$ (Lee, 2002). Water holding capacity of the soil, measured by the pressure plate method (Cassel and Nielsen, 1986), is 0.09 $\mathrm{cm}^{3} \mathrm{~cm}^{-3}$ in the top $1 \mathrm{~m}$ of soil. Mean annual precipitation is $1220 \mathrm{~mm}$ and mean annual temperature is $17^{\circ} \mathrm{C}$ (Albaugh et al., 1998). Loblolly pine was planted in 1985, and current stand density is 1260 trees ha ${ }^{-1}$.

The established statistical design for SETRES consists of a $2 \times 2$ factorial combination of fertilization, irrigation, and fertilization plus irrigation in addition to an unfertilized, nonirrigated control. Four replicate blocks were established, with $50 \times 50 \mathrm{~m}$ plots containing $30 \times 30 \mathrm{~m}$ measurement plots surrounded by a $10-\mathrm{m}$ perimeter. Fertilizer treatments at SETRES commenced in March of 1992 with the applications of $\mathrm{N}$ and additional macro- and micronutrients, based on optimum foliar nutrient levels for $\mathrm{N}, \mathrm{P}, \mathrm{K}, \mathrm{Ca}, \mathrm{Mg}, \mathrm{S}$, and $\mathrm{B}$. Optimum foliar levels were defined as a $\mathrm{N}$ concentration of $1.3 \%$ and macronutrient/nitrogen ratios of $0.1,0.35,0.12,0.06$, with B maintained at foliar levels $>12 \mathrm{mg} \mathrm{kg}^{-1}$. Fertilization has continued on an annual basis following foliar nutrient assessment. Irrigation treatments, using nozzles on $35-\mathrm{cm}$ risers on a $10 \times 10 \mathrm{~m}$ grid, were implemented in March of 1993 , with growing-season applications maintaining an available soil-water content of $40 \%$ to maintain photosynthesis and growth. In 2000, a target application of $650 \mathrm{~mm}$ above rainfall evenly applied throughout the growing season $(2.5 \mathrm{~cm}$ per irrigation event, March to November) was set. Understory growth is controlled with glyphosate to minimize water and nutrient competition (Abrahamson et al., 1998).

\section{Sampling}

Samples were taken from control, fertilized, and fertigated plots on three of the four blocks in October 2000 and again from block 2 in April 2001 (post-fertilization). Each $30 \times 30 \mathrm{~m}$ measurement plot was divided into a regular grid of $5 \times 5 \mathrm{~m}$ subplots. One randomly chosen point within each of these $5 \times$ $5 \mathrm{~m}$ subplots was sampled for a total of 36 samples in each $900-\mathrm{m}^{2}$ measurement plot. At the selected random point in each subplot, the $\mathrm{O}$ horizon profile was subdivided into fresh litter (Oi or whole needles) and fermentation (Oe or partially decomposed needles) layers for in situ measurement of depth by ruler. In situ, we also measured surface soil moisture (0-15 cm, ThetaProbe, Delta-T Devices Co., UK). Subsequently, the Oi horizon was removed and soil cores $(8-\mathrm{cm}$ diam.) taken from the top of the fermentation horizon to a depth of $5 \mathrm{~cm}$ below the soil surface. The aim of this strategy was to sample the combined soil and forest floor zone where fine root development was maximal. Field-moist soil and organic material was passed through a nest of sieves (4-, 2-, and 1-mm mesh size) to separate root sections and woody debris, homogenized and subsequently air-dried and then stored at $4^{\circ} \mathrm{C}$ until analysis.

\section{Chemical Analyses}

Standard laboratory analyses were conducted on all samples, including soil $\mathrm{pH}(4: 11 \mathrm{M} \mathrm{KCl} /$ soil ratio, Thomas, 1996); TOC (\% TOC; oven-dried sample), and TN (\% TN; oven-dried sample) measured by combustion at $600^{\circ} \mathrm{C}$ (LECO 600 carbon/ nitrogen analyzer, LECO Corp., St. Joseph, MI). Potentially plant available $\mathrm{NH}_{4}^{+}-\mathrm{N}$ was extracted with $1 \mathrm{M} \mathrm{KCl}$ and deter- mined colorimetrically (Mulvaney, 1996). Potentially plant available $\mathrm{Al}^{3+}$ was also recovered in $1 M \mathrm{KCl}$, and $\mathrm{Ca}^{2+}$ and $\mathrm{Mg}^{2+}$ were extracted from soil samples using $0.5 \mathrm{M}$ ammonium acetate (Suarez, 1996; Bertsch and Bloom, 1996). Cations were determined by inductively coupled plasma-optical emission spectrometry (ICP-OES).

\section{Statistical and Geostatistical Analyses}

Analysis of variance was conducted to determine if parameters differed significantly among management treatments (Proc Mixed, SAS Institute, 1999). Oi and Oe depth, soil moisture content, and ammonium content were log transformed. Calcium and Al contents were square root transformed. Separation of means was assessed using Tukey's Honestly Significant Difference (HSD).

To quantitatively assess the degree of spatial dependence that existed for $\mathrm{Ca}^{2+}, \mathrm{NH}_{4}^{+}$, and soil moisture content in the SETRES plots, the geostatistical program $\mathrm{GS}^{+}$Version 5.1 (Gamma Design Software 1990-2001, Gamma Design Software, Plainwell, MI) was used to construct isotropic semivariograms. Spherical, exponential, linear, linear to sill, and Gaussian models were fit to the semivariogram data, and the best-fit model selected based on both highest $r^{2}$ and lowest residual sum of squares (Trangmar et al., 1987). The proportion of spatial structure was calculated as $C / C_{\mathrm{o}}+C$, where $C_{\mathrm{o}}+C=$ sample variance and $C=$ structural variance. In addition, the distance over which spatial autocorrelation is observed was determined as the 'effective range'. Significant differences in effective range were determined by ANOVA. To maximize the comparability of the data, different lag class distance intervals were initially explored, and best-fit models were subsequently selected for semi-variogram data derived from models with lag-distance class intervals of 3 to $4 \mathrm{~m}$ and a maximum lag distance of $26 \mathrm{~m} \mathrm{(70 \%} \mathrm{of} \mathrm{maximum} \mathrm{distance} \mathrm{between} \mathrm{two}$ points). This approach ensured that the mean semi-variance in any one-lag class was determined from a minimum of 12 pairs of points, and that the semivariograms did not decompose at large lag intervals. Both the proportion of spatial structure and effective range of the best-fit model were calculated automatically by $\mathrm{GS}^{+}$. Point-kriging based on the semivariance models was used to develop spatially explicit maps of $\mathrm{Ca}^{2+}$ and $\mathrm{NH}_{4}^{+}$availability in both fall 2000 and spring 2001 for the treatment plots of SETRES Block 2.

\section{RESULTS Treatment Effects}

The most obvious effect of sustained optimal fertilization at SETRES, other than the clear increase in loblolly pine height and stem diameter reported by Albaugh et al. (2004), is the increased depth of the forest floor. Over the site as a whole, forest floor depth ranged from $<10$ to $>50 \mathrm{~mm}$, and mean forest floor depth was significantly higher on the optimally fertilized plots (Table 1). As expected, the mean moisture content of the fertigated plots in the fall was also significantly higher than non-irrigated plots (Table 1).

Total organic $\mathrm{C}$ and TN contents of the SETRES soil ranged from 0.5 to $11 \%$ and $<0.002$ to $0.37 \%$ respectively, and although there was a trend toward increased TOC and TN contents in the soil of optimally fertilized and fertigated treatments, this was not significant (Table 1). The SETRES soil generally is acidic, with $\mathrm{pH}$ ranging from 2.8 to 4.5 , but our results indicated a signifi- 
Table 1. Forest floor depth, total organic C (TOC) content, total N (TN) content, pH, soil moisture, and salt-extractable NH $\mathrm{N}_{4}^{+}$Ca, Mg, and Al contents of the natural (Control), optimally fertilized (Fertilized), and optimally fertilized and irrigated (Fertigated) soils at the South Eastern Tree Research and Education Site, North Carolina, in October 2000.

\begin{tabular}{|c|c|c|c|c|}
\hline & Control $\dagger$ & Fertilized $\dagger$ & Fertigated $\dagger$ & $p$-value $\ddagger$ \\
\hline Forest floor, cm & $1.16 \pm 0.12$ (a) $\S$ & $2.92 \pm 0.27(b)$ & $3.04 \pm 0.22$ (b) & 0.001 \\
\hline TOC, \% & $2.99 \pm 0.19$ & $3.26 \pm 0.16$ & $3.15 \pm 0.13$ & 0.52 \\
\hline $\mathbf{T N}, \%$ & $0.07 \pm 0.004$ & $0.08 \pm 0.004$ & $0.11 \pm 0.034$ & 0.26 \\
\hline $\mathbf{p H}_{(\mathrm{CaCl} 2)}$ & $3.33 \pm 0.02$ (a) & $3.50 \pm 0.05$ (b) & $3.43 \pm 0.01(a b)$ & $\mathbf{0 . 0 3}$ \\
\hline Soil moisture, \% & $2.54 \pm 0.15$ (a) & $3.00 \pm 0.55$ (a) & $5.73 \pm 0.63$ (b) & 0.007 \\
\hline $\mathrm{NH}_{4}^{+}, \mathrm{mg} \mathrm{kg}^{-1} \mathrm{I}$ & $3.26 \pm 0.53$ (a) & $4.71 \pm 0.82(\mathrm{ab})$ & $6.53 \pm 1.06(\mathrm{~b})$ & 0.008 \\
\hline $\mathrm{Ca}^{2+}, \mathrm{mg} \mathrm{kg}{ }^{-1} \#$ & $20.85 \pm 3.28$ (a) & $42.18 \pm 1.77$ (b) & $28.80 \pm 0.92$ (a) & 0.001 \\
\hline $\mathrm{Mg}^{2+}, \mathbf{m g ~ k g} \mathbf{~}^{-1} \#$ & $2.35 \pm 0.38$ (a) & $7.27 \pm 0.53$ (c) & $4.69 \pm 0.20(\mathrm{~b})$ & 0.0004 \\
\hline $\mathbf{A l}^{3+}, \mathbf{m g ~ k g}^{-1} \mathbf{I}$ & $5.14 \pm 0.18$ (a) & $3.63 \pm 0.32$ (b) & $3.61 \pm 0.22$ (b) & 0.007 \\
\hline
\end{tabular}

+ Mean values and SE $(n=108)$.

$\uparrow p$-values for ANOVA, variable $=$ treatment; treatment $F_{2,6}$ df.

$\S$ Values within a row followed by different letters are significantly different at $\alpha=0.05$ (Tukey's HSD).

II $1 M$ KCl extraction.

\# 0.5 M Ammonium acetate extraction.

cant decrease in acidity in the soil of optimally fertilized plots (Table 1). This was most likely due to a significant decrease in exchangeable $\mathrm{Al}^{3+}$, and concomitant increases in exchangeable $\mathrm{Ca}^{2+}$ and $\mathrm{Mg}^{2+}$ in the soils of the optimally fertilized plots (Table 1). Exchangeable $\mathrm{NH}_{4}^{+}$concentrations were also significantly higher in the fertilized plots at the end of the 2000 growing season (Table 1). Inspection of Table 1 also shows that although optimal fertilization generally had significant effects on the soil chemistry of these nutrient poor loblolly pine stands, the effect of fertigation was different from that of fertilization alone. In particular, $\mathrm{Ca}^{2+}, \mathrm{Mg}^{2+}$, and $\mathrm{Al}^{3+}$ concentrations were lower in the irrigated soils, and $\mathrm{pH}$ closer to that of the unfertilized control soils. This suggests either that irrigation improved plant access to the nutrients (i.e., improved uptake) or acted to flush cations below the root zone of the plants.

In comparison with the fall data, results from spring 2001 showed that the soil of all treatments had significantly higher moisture contents (Table 2). The extractable concentrations of $\mathrm{Ca}^{2+}$ and $\mathrm{Mg}^{2+}$ were significantly lower in the spring in all treatments, as was the concentration of extractable $\mathrm{NH}_{4}^{+}$on the control plot (Table 2). As our sampling occurred within $10 \mathrm{~d}$ of urea fertilization, significantly higher concentrations of $\mathrm{NH}_{4}^{+}$were recorded in the optimally fertilized soils (Table 2). Interestingly, although the magnitudes of $\mathrm{NH}_{4}^{+}, \mathrm{Ca}^{2+}$, and $\mathrm{Mg}^{2+}$ differed between fall 2000 and spring 2001, the pattern of their distribution between treatments, especially the similarity of their comparative magnitudes on optimally fertilized and fertigated plots, suggest that differences in soil chemistry induced by irrigation persist over winter and into the next growth season.

\section{Spatial Distribution of $\mathrm{Ca}^{2+}$ availability}

Calcium has not been added to the optimally fertilized plots at SETRES since 1996 (Albaugh et al., 2004). The availability of $\mathrm{Ca}^{2+}$ in the forest floor and soil at SETRES therefore reflects the balance between release from litter, biological uptake, and leaching loss. As described previously, $\mathrm{Ca}^{2+}$ availability was significantly higher on the optimally fertilized plots, and this may reflect both the increased depth of the forest floor and the faster decomposition rates of litter from fertilized loblolly pine (Sanchez, 2001).

Semivariance analysis revealed that the proportion of $\mathrm{Ca}^{2+}$ variance that could be attributed to spatial structure ranged from 26 to $90 \%$, and was typically highest on the control plots (mean control, $85.5 \%$; mean fertilized, $56.7 \%$; mean fertigated, $56.3 \%$ ). Exponential and/or spherical models gave the best fits to data (Fig. 1), and effective ranges for $\mathrm{Ca}^{2+}$ ranged from 8.31 to $129.75 \mathrm{~m}$ (Table 3). The mean effective range of $\mathrm{Ca}^{2+}$ was significantly higher in the fertilized and fertigated plots than in the controls (Table 3). Effective ranges for $\mathrm{Ca}^{2+}$ in the three treatment plots of Block 2 in spring 2001 were similar to the values determined the previous fall (Control: 8.73 m FALL, 15.2 m SPRING; Fertilized $53.5 \mathrm{~m}$ FALL, $61 \mathrm{~m}$ SPRING; Fertigated, $157 \mathrm{~m}$ FALL, $137 \mathrm{~m}$ SPRING; $p=0.42$, one-sided paired $t$-test), suggesting that despite the lower concentrations of $\mathrm{Ca}^{2+}$ recorded in spring, there was little change in the spatial distribution of this nutrient.

Kriged maps of $\mathrm{Ca}^{2+}$ distribution across the three treatment plots of SETRES Block 2 are shown in Fig. 2. The maps (Fig. 2) clearly revealed the patchier nature of $\mathrm{Ca}^{2+}$ availability on the control plot relative to the two optimally fertilized plots. Calcium availability was lowest on the southwestern and northeastern edges of the optimally fertilized plot, whereas lowest availability occurred in a broad band running northwest to southeast on the optimally fertilized and irrigated plot (Fig. 2). Generally, these spatial patterns of availability were observed again in spring 2001 (Fig. 3); lowest $\mathrm{Ca}^{2+}$ avail-

Table 2. Soil moisture content and salt-extractable ammonium and calcium, contents of the natural (Control), optimally fertilized (Fertilized), and optimally fertilized and irrigated (Fertigated) soils at the South Eastern Tree Research and Education Site, North Carolina, in April 2001.

\begin{tabular}{|c|c|c|c|}
\hline & Control $\dagger$ & Fertilized $\dagger$ & Fertigated $\dagger$ \\
\hline Soil moisture, \% & $10.5 \pm 0.75 \ddagger * * *$ & $8.85 \pm 0.62 * * * *$ & $12.7 \pm 0.65^{* * * *}$ \\
\hline $\mathrm{NH}_{4}^{+}, \mathrm{mg} \mathrm{kg}^{-1} \S$ & $1.45 \pm 0.14 * * *$ & $12.3 \pm 3.16^{* *} *$ & $15.8 \pm 4.48^{* *}$ \\
\hline $\mathrm{Ca}^{2+}, \mathrm{mg} \mathrm{kg}^{-1} \mathbf{I}$ & $10.3 \pm 1.41 * * *$ & $22.0 \pm 2.04 * *$ & $13.3 \pm 2.30 * * *$ \\
\hline
\end{tabular}



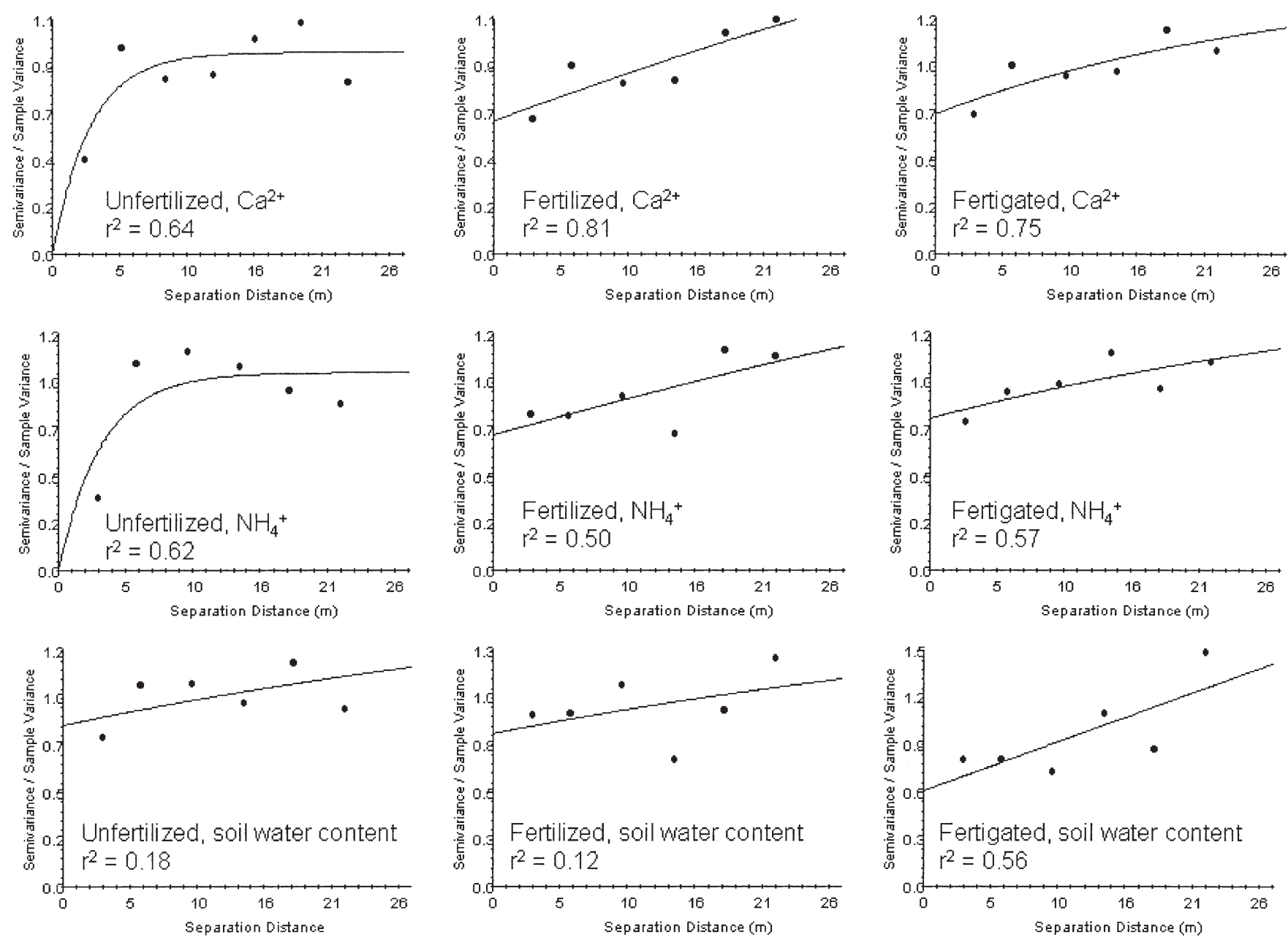

Fig. 1. Standardized, isotropic semivariograms for $\mathrm{Ca}^{2+}$ availability, $\mathrm{NH}_{4}^{+}$availability, and soil water content in the unfertilized control, fertilized, and fertilized and irrigated (fertigated) plots of SETRES Block 2 in October 2000.

ability on the optimally fertilized plot were the eastern and southwestern edges, and in a broad band running northwest to southeast on the fertigated plot.

\section{Spatial Distribution of $\mathrm{NH}_{4}^{+}$availability}

Nitrogen fertilization has occurred every spring at SETRES since treatments were initiated, and the optimally fertilized plots received manual applications of approximately $60 \mathrm{~kg} \mathrm{ha}^{-1} \mathrm{~N}$ as urea in 2000 and 2001 (Albaugh et al., 2004). Fertilization clearly increased $\mathrm{NH}_{4}^{+}$availability in the spring (Table 2), although end of growth season $\mathrm{NH}_{4}^{+}$availability was also typically higher on the optimally fertilized and fertigated plots than on the unfertilized control (Table 1). The propor- tion of the variance in $\mathrm{NH}_{4}^{+}$availability that could be attributed to spatial structure ranged from 50 to $99 \%$, and as for $\mathrm{Ca}^{2+}$ was typically highest on the unfertilized control plots (mean control, $83 \%$; mean fertilized, $63 \%$; mean fertigated, 57\%). Exponential and/or spherical models gave the best fits to data (Fig. 1), and effective ranges for $\mathrm{NH}_{4}^{+}$ranged from 8.55 to $160 \mathrm{~m}$. As for $\mathrm{Ca}^{2+}$, mean effective range for $\mathrm{NH}_{4}^{+}$was significantly higher in the fertilized and fertigated plots than in the controls in the fall (Table 3).

The effective range of $\mathrm{NH}_{4}^{+}$availability in the control plot of Block 2 in spring 2001 was very similar to the range determined in the fall $\left(\mathrm{NH}_{4}^{+} 9.52 \mathrm{~m}\right.$ FALL, 9.2 $4 \mathrm{~m}$ SPRING), and kriged maps of $\mathrm{NH}_{4}^{+}$availability on

Table 3. Effective ranges (m) for salt extractable calcium and ammonium, and for soil moisture content of the natural (Control), optimally fertilized (Fertilized), and optimally fertilized and irrigated (Fertigated) soils at the South Eastern Tree Research and Education Site, North Carolina, in October 2000.

\begin{tabular}{|c|c|c|c|c|}
\hline & Control $\dagger$ & Fertilized $\dagger$ & Fertigated $\dagger$ & $p$-value + \\
\hline $\mathrm{Ca}^{2+}, \mathrm{m}$ & $25.7 \pm 11 \mathrm{a}$ & $55.2 \pm$ 17.1ab & $81.4 \pm 19.8 b$ & 0.02 \\
\hline $\mathbf{N H}_{4}^{+}, \mathbf{m}$ & $24.5 \pm 12.2 \mathrm{a}$ & $81.7 \pm 31.7 a b$ & $169.2 \pm 18.9 b$ & 0.04 \\
\hline Soil moisture content, $m$ & $<10 \S$ & $61 \mathrm{I}$ & 13.7I & $\mathbf{N} / \mathbf{A}$ \\
\hline
\end{tabular}

$\dagger$ Treatment means $\pm \mathrm{SE}(n=3)$.

$+p$-values for ANOVA, effective range $=$ treatment; treatment with $F_{2,4}$ df. $\S$ Spatial structure observed on two of three replicate plots.

II Spatial structure seen on a single plot. 


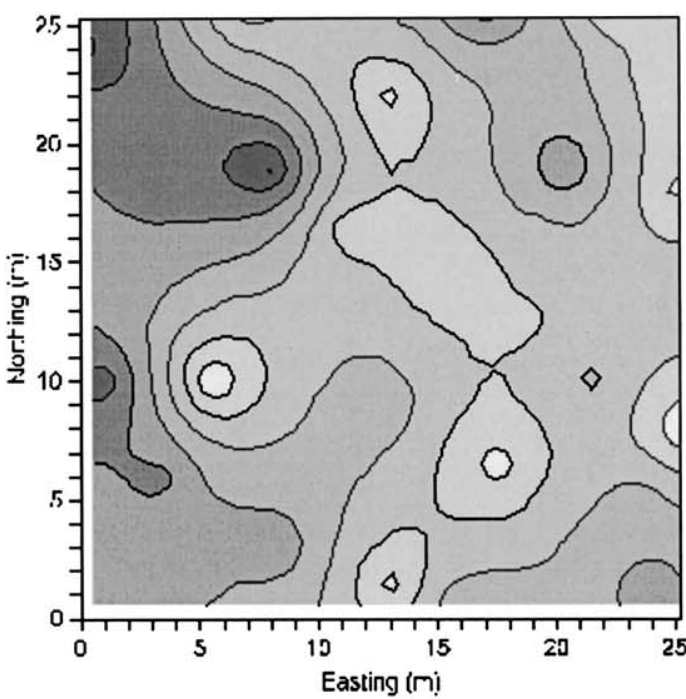

\section{Unfertilized control}

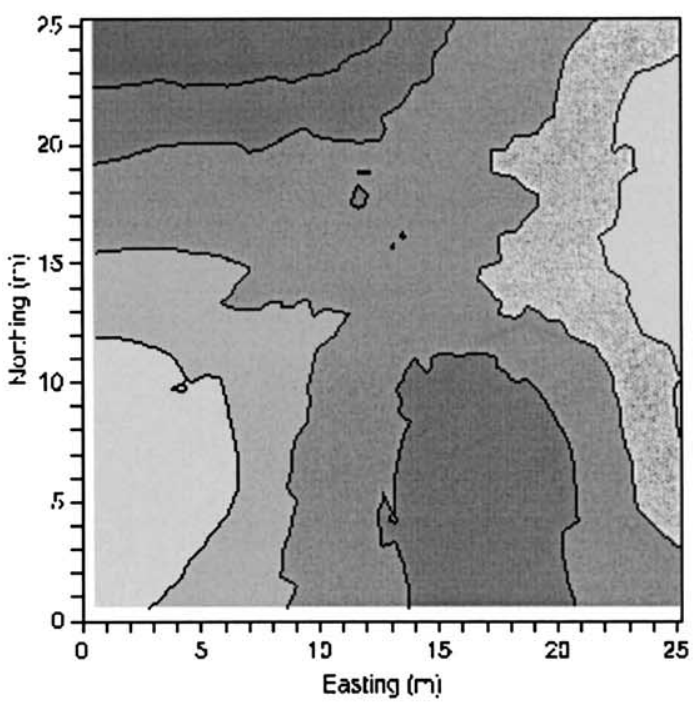

\section{Fertilized}
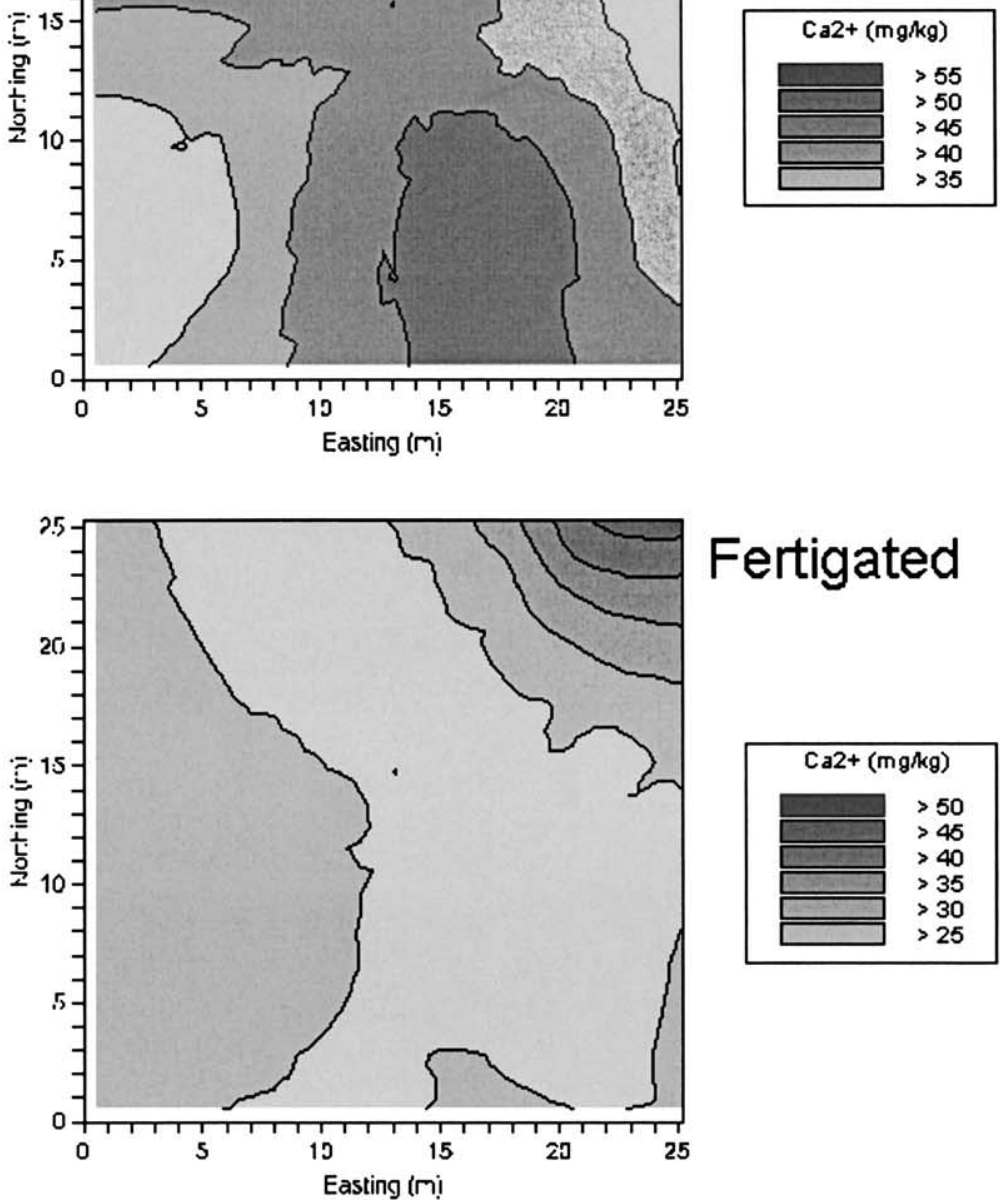

Fertigated

Fig. 2. Point-kriged maps showing spatial distribution of $\mathrm{Ca}^{2+}$ availability in the unfertilized control, optimally fertilized, and optimally fertilized and irrigated (fertigated) plots of SETRES Block 2 in October 2000. 


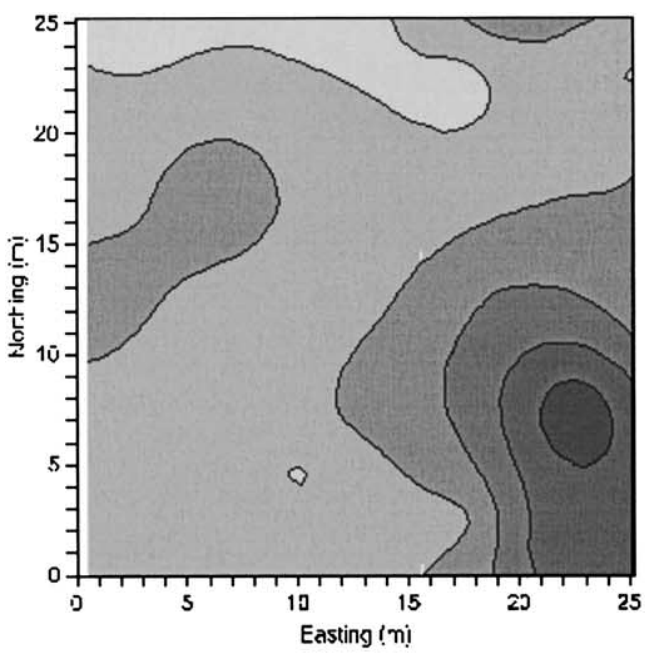

\section{Unfertilized control}

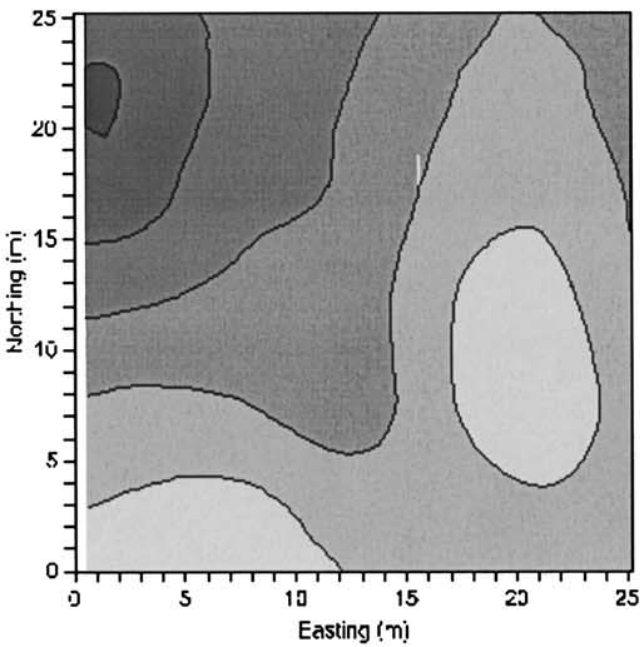

Fertilized
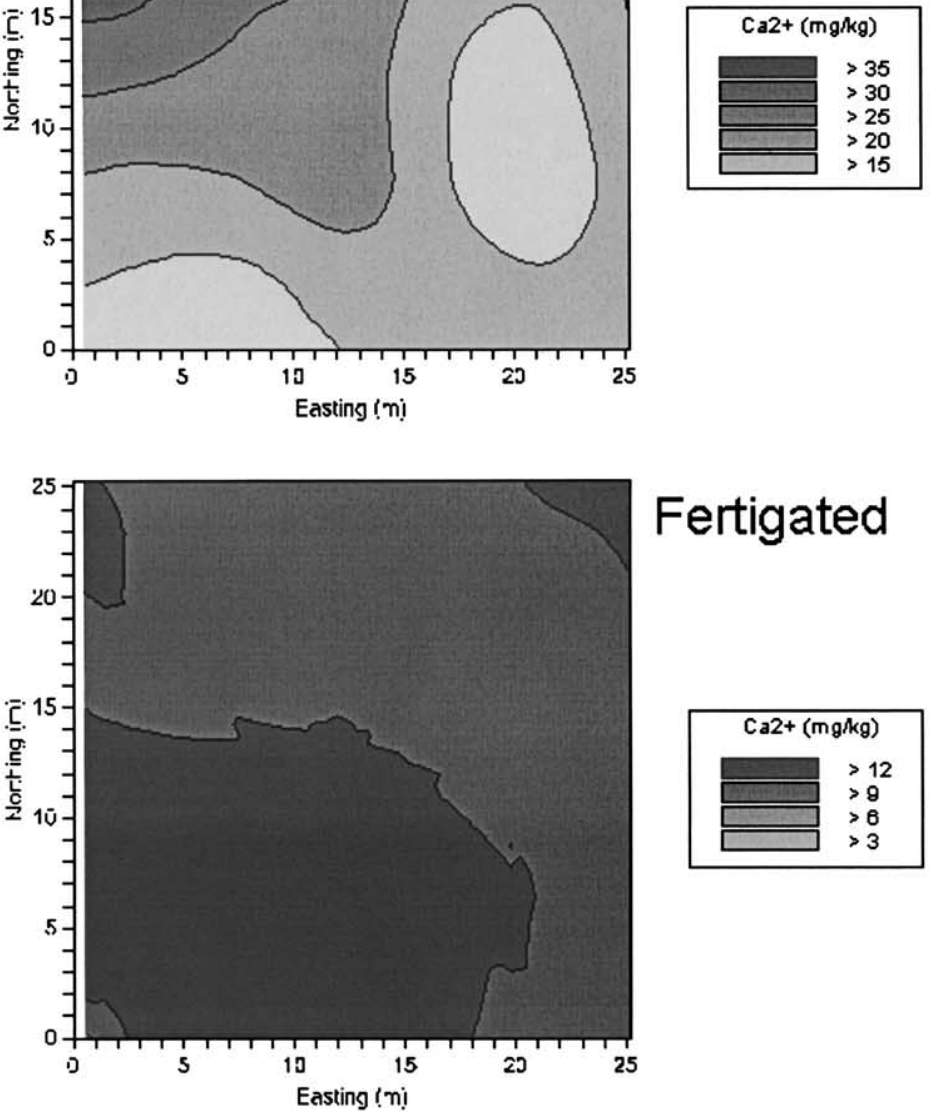

Fertigated

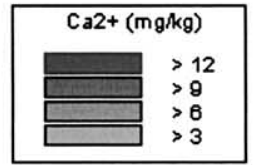

Fig. 3. Point-kriged maps showing spatial distribution of $\mathrm{Ca}^{2+}$ availability in the unfertilized control, optimally fertilized, and optimally fertilized and irrigated (fertigated) plots of SETRES Block 2 in April 2001.

this plot (not shown) revealed a patchy distribution similar to that seen for $\mathrm{Ca}^{2+}$ (Fig. 3). In contrast to this, spring estimates of $\mathrm{NH}_{4}^{+}$effective range in both of the fertilized treatment plots were much smaller than recorded in the fall (Fertilized, $61 \mathrm{~m}$ FALL, $10.2 \mathrm{~m}$ SPRING; Fertigated 134 m FALL, 48.8 m SPRING).
As smaller autocorrelation ranges indicate a patchier, less homogeneous distribution, our results suggest that the spring application of urea initially increased the complexity of $\mathrm{NH}_{4}^{+}$distribution at this site. This contrasting spatial pattern of $\mathrm{NH}_{4}^{+}$availability in the optimally fertilized plots of Block 2 is shown in Fig. 4. The 
October 2000
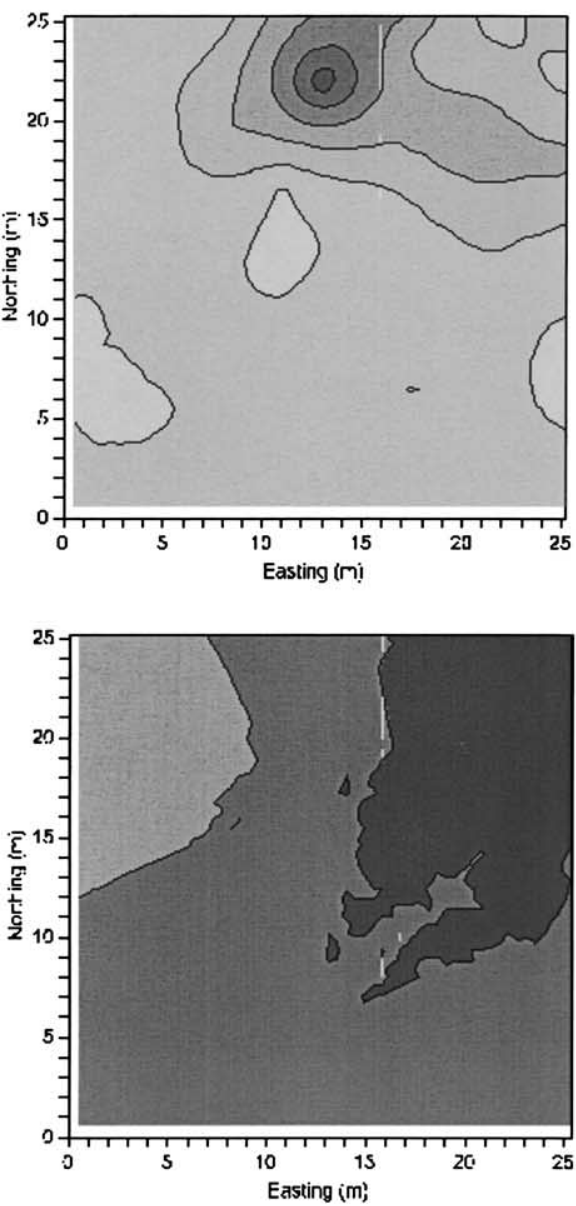
$\mathrm{ha}^{-1}$ in April 2001.
April 2001
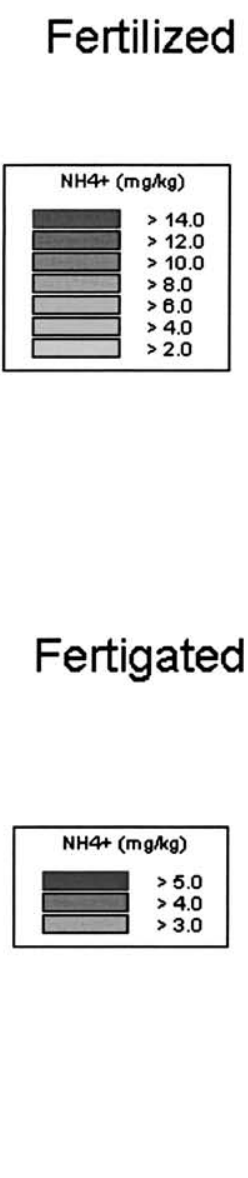
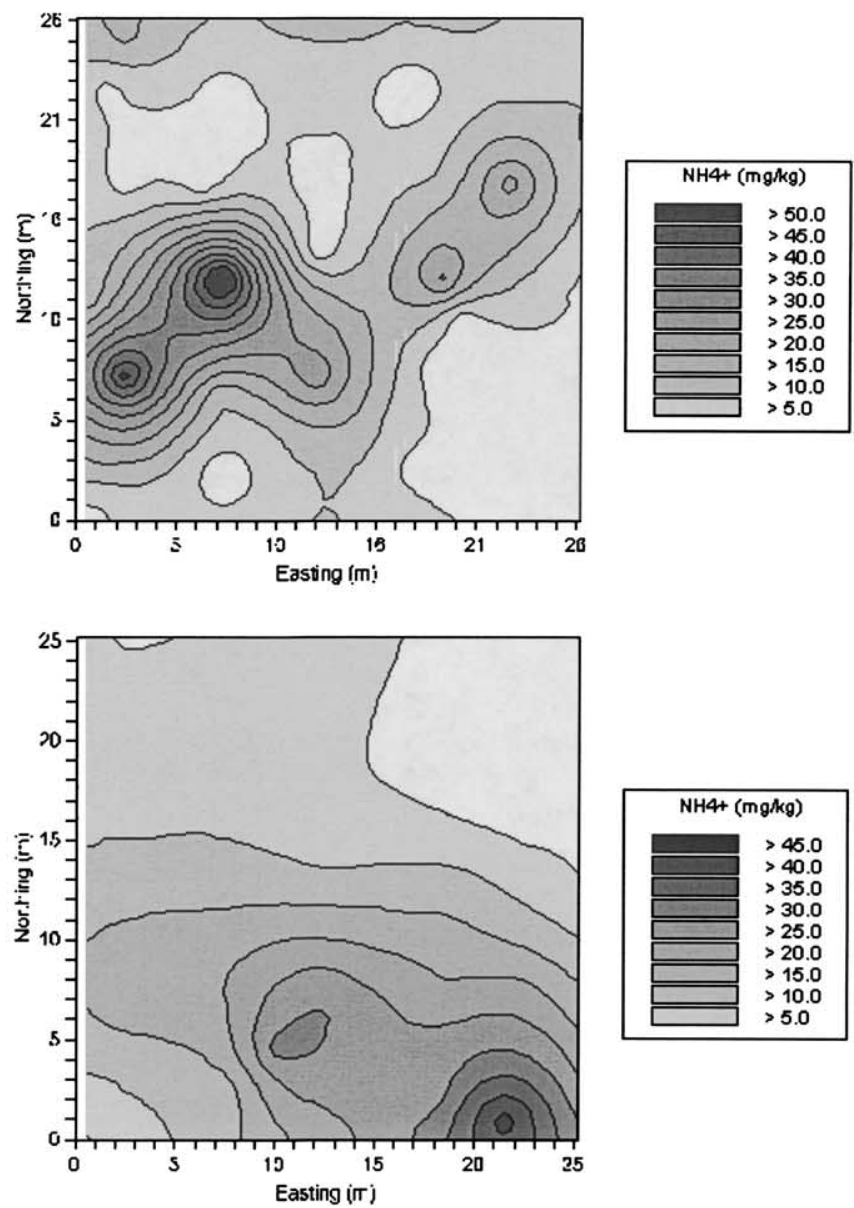

ig. 4. Point-kriged maps showing the contrasting spatial distributions of $\mathrm{NH}_{4}^{+}$availability in the optimally fertilized and optimally fertilized and irrigated (fertigated) plots of SETRES Block 2 at the end of the growing season in October 2000 and after manual application of $60 \mathrm{~kg}$ urea

kriged maps (Fig. 4) suggest that for both of these plots, the application of urea in spring 2001 was heavier along the southern half of the plots, and that $\mathrm{NH}_{4}^{+}$availability on the northern halves of the plots remained little changed compared with the previous fall.

\section{Spatial Distribution of Soil Water Content}

In contrast to both cations, most attempts to fit semivariogram models to the soil moisture content data resulted in weak fits to linear or exponential models (Fig. 1), indicating that no strong pattern of spatial structure could be found. Two control plots showed an effective range for soil moisture of $<10 \mathrm{~m}$, and one fertilized and one fertilized and irrigated plot gave ranges of 61 and $13.74 \mathrm{~m}$ respectively, but overall we were not able to discern any clear treatment related differences in the spatial distribution of soil water content, despite a clear difference in water content in the irrigated plots in the fall of 2000 (Table 1).

\section{DISCUSSION}

Currently, commercial forest practices recognize the need for spatial uniformity of seedbeds and intensive management at the nursery stage to maximize seedling development and outplanting success (South et al., 2001). At the same time, as typical rotation lengths decrease, there is an increasing interest in developing site preparation methods aimed at homogenizing planting sites to maintain the favorable growth conditions created in the nursery (South et al., 2001). However, there have been few studies devoted to examining how subsequent forest management affects the spatial patterns of soil properties, and these have mainly focused on harvest effects (Shaw and Carter, 2002; Guo et al., 2004). Our study shows that optimal nutrition management can have significant effects on both the residual availability (i.e., at the end of the growing season) of nutrients such as calcium and ammonium (Table 1), and on their spatial distribution (Fig. 2 to 4; Table 3). In comparison with the unfertilized plots, where the effective range of semi-variance was typically $<30 \mathrm{~m}$, similar to that seen in natural forests (Gallardo, 2003), the optimally fertilized plots showed less spatial variability, with effective ranges often closer to or even in excess of $100 \mathrm{~m}$ (Table 3). Reduced spatial variability for $\mathrm{Ca}^{2+}$ in the optimally fertilized plots, despite the absence of $\mathrm{Ca}^{2+}$ fertilization for $6 \mathrm{yr}$, and close agreement between spring and fall $\mathrm{Ca}^{2+}$ effective range estimates, indicate that the effects of optimal nutrition management on soil 
nutrient spatial properties can be long-lasting. Our results are therefore in agreement with Guo et al. (2004), who have previously observed that harvesting effects on nutrient distribution can last for $4 \mathrm{yr}$ or more. However it is important to remember that Guo et al. (2004) found that harvesting increased spatial variability, whereas our results show that optimal nutrition during stand development decreases spatial variability. Further studies will therefore be needed to determine the effect of harvesting on the nutrient distributions of long-term optimally fertilized stands, and to assess the extent and type of site preparation subsequently required to optimize the soil for replanting.

Our results also indicate that nutrient distributions are less variable when irrigation is used in combination with fertilization (Table 3). This effect was clear for both $\mathrm{Ca}^{2+}$ and $\mathrm{NH}_{4}^{+}$, even though we found no geostatistical evidence for improved water distribution at the site. The combination of optimal fertilization and irrigation has been shown to increase productivity over optimal nutrition alone at this site (Albaugh et al., 1998). However, as loblolly pine roots show a radial growth form and limited morphological plasticity (Mou et al., 1997) it is also reasonable to ask if this increased homogeneity of nutrient distribution results in a more homogenous crop? Figure 5 shows loblolly pine stem diameter classes for optimally fertilized and fertigated treatments at SETRES in the Year 2000 (data from Albaugh et al., 2004). Median diameter class for both treatments is $20 \mathrm{~cm}$, and although the optimally fertilized distribution shows a slightly greater skew toward smaller size classes than the fertigated, there is little difference between the distributions of each treatment. We feel that this result may in large part result from manual application of the fertilizer, as this creates a heterogeneous nutrient distribution early in the growth season (Fig. 4). Further improvements in loblolly pine productivity may therefore be achieved if steps are taken to more effectively

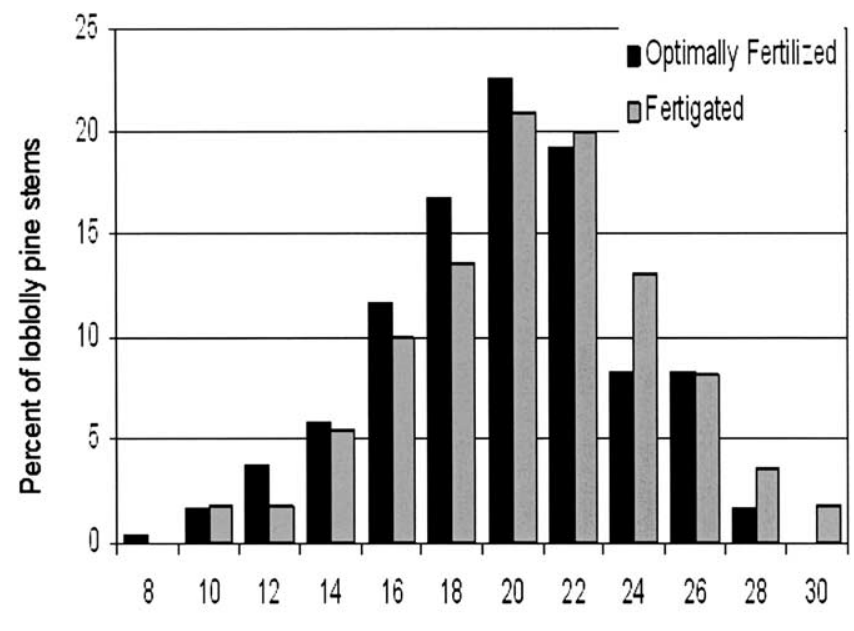

Diameter class midpoint $(\mathrm{cm})$

Fig. 5. Loblolly pine stem diameter size class distributions on optimally fertilized and optimally fertilized and irrigated plots at South Eastern Tree Research and Education Site, North Carolina, in 2000. Data from Albaugh et al. (2004). homogenize spring nutrient distribution, for example by adding fertilizer in liquid form, via the irrigation outlets (Bergh et al., 1999). Alternatively, soil sampling in the fall could be combined with semi-variance analysis and kriging to produce spatially explicit descriptions of plot-scale nutrient distribution (Fig. 2 and 4), and this information could in turn be used to optimize the spring fertilization strategy. Although the need to conduct semivariance analysis and kriging before map construction is slightly more labor-intensive compared with producing simple loess or inverse-squared distance interpolation maps, the final distribution maps are based on a spatially explicit model of the data, and therefore tend to be a more accurate description of the true distribution patterns. A more serious limitation may be that sampling commercial plantations, which often extend over several tens of hectares, at the same intensity that we used at SETRES (30-40 samples per hectare) will prove impracticable. However, the results of our study do show that even though a truly homogeneous distribution of for example, $\mathrm{N}$ is not achieved by optimal fertilization, nevertheless the range of spatial dependence increases, often to around $100 \mathrm{~m}$ (Table 3 ). It may therefore be possible to map the distribution of plant growth limiting nutrients such as $\mathrm{N}$ on a larger scale using as little as 1 sample per hectare, although future work should examine the extent to which important small-scale information is lost by this approach.

Although an increased homogeneity of nutrient distribution may provide productivity benefits in the long term, it is also essential to consider the possible side effects of such an approach on non-target organisms within the loblolly ecosystem. Like all pines, loblolly pine relies on mycorrhizal fungi for much of its nutrient uptake (Rousseau et al., 1994). We have previously found at the SETRES site that the increased $\mathrm{N}$ availability of optimally fertilized treatments alters the species composition of the mycorrhizal community (Edwards et al., 2004), and that increased homogeneity of $\mathrm{N}$ distribution appears to favor the mycelial expansion of certain species at the expense of others. Although increased mycelial expansion may lead to greater interplant connectivity, and reduce competition for nutrient uptake (Simard and Durall, 2004), the possibility remains that loblolly pine ecosystems will be less able to respond to environmental change if mycorrhizal fungal diversity is reduced (Leake, 2001; Godbold et al., 1997). Further studies of the long-term impact of optimal nutrition systems on non-target organisms within the loblolly ecosystem, and on the feedbacks between these impacts and sustained productivity in a changing environment are therefore required.

\section{ACKNOWLEDGMENTS}

We extend our thanks to Pete Anderson for his help and hospitality at the SETRES site in North Carolina, and to the staff of the USDA-ARS National Soil Erosion Research Laboratory at Purdue University for assistance with the chemical analyses. We also thank three anonymous reviewers for their thoughtful feedback to earlier versions of this paper. This research was supported by the U.S. Forest Service through a 
grant under the Agenda 2020 program. Paper number 17707 of the Purdue Agricultural Experiment Station Series.

\section{REFERENCES}

Abrahamson, D.A., P.M. Dougherty, and S.J. Zarnoch. 1998. Hydrological components of a young loblolly pine plantation on a sandy soil with estimates of water use and loss. Water Resour. Res. 34: 3503-3512.

Albaugh, T.J., H.L. Allen, P.M. Dougherty, and K.H. Johnsen. 2004 Long term growth responses of loblolly pine to optimal nutrient and water resource availability. For. Ecol. Manage. 192:3-19.

Albaugh, T.J., H.L. Allen, P.M. Dougherty, L.W. Kress, and J.S. King. 1998. Leaf area and above- and belowground growth responses of loblolly pine to nutrient and water additions. For. Sci. 44:317-328.

Bergh, J., S. Linder, T. Lundmark, and B. Elfving. 1999. The effect of water and nutrient availability on the productivity of Norway spruce in northern and southern Sweden. For. Ecol. Manage. 119:51-62.

Bertsch, P.M., and P.R. Bloom. 1996. Aluminum. p. 517-550. In D.L. Sparks (ed.) Methods of soil analysis. Part III. SSSA Book Series No. 5. SSSA, Madison, WI.

Bradshaw, H.D., Jr., and S.H. Strauss. 2000. Breeding strategies for the 21st century: Domestication of poplar. p. 383-394. In D.I. Dickmann et al. (ed.) Poplar culture in North America. Part 2. NRC Research Press, National Research Council of Canada, Ottawa, Canada.

Cassel, D.K., and D.R. Nielsen. 1986. Field capacity and available water capacity. p. 901-926. In A. Klute (ed.) Methods of soil analysis. Part I. 2nd ed. Agron. Monogr. No. 9. ASA and SSSA, Madison, WI.

Edwards, I.P., J.L. Cripliver, A.R. Gillespie, K.H. Johnsen, M. Scholler, and R.F. Turco. 2004. Nitrogen availability alters macrofungal basidiomycete community structure in optimally fertilized loblolly pine forests. New Phytol. 162:755-770.

Gallardo, A. 2003. Spatial variability of soil properties in a floodplain forest in northwest Spain. Ecosystems 6:564-576.

Godbold, D.L., G.M. Berntson, and F.A. Bazzaz. 1997. Growth and mycorrhizal colonization of three North American tree species under elevated atmospheric $\mathrm{CO}_{2}$. New Phytol. 137:433-440.

Guo, D.L., P. Mou, R.H. Jones, and R.J. Mitchell. 2004. Spatio-temporal patterns of soil available nutrients following experimental disturbance in a pine forest. Oecologia 138:613-621.

Leake, J.R. 2001. Is diversity of ectomycorrhizal fungi important for ecosystem function? New Phytol. 152:1-8.

Lee, Y.S. 2002. Retention of fertilizer nitrogen by a pine forest eco- system supported by a sandy, leachable soil. M.S. thesis, Nicholas School of Env. and Earth Sci., Duke Univ., Durham, NC.

McKeand, S.E., R.P. Crook, and H.L. Allen. 1997. Genotypic stability effects on predicted family responses to silvicultural treatments in loblolly pine. South. J. Appl. For. 21:84-89.

Mou, P., R.J. Mitchell, and R.H. Jones. 1997. Root distribution of two tree species under a heterogeneous nutrient environment. J. Appl. Ecol. 34:645-656.

Mulvaney, R.L. 1996. Nitrogen-Inorganic Forms. p. 1123-1184. In D.L. Sparks (ed.) Methods of soil analysis. Part III. SSSA Book Series No. 5. SSSA, Madison, WI.

Robertson, P.H., M.A. Huston, F.C. Evans, and J.M. Tiedje. 1988 Spatial variability in a successional plant community: Patterns of nitrogen availability. Ecology 69:1517-1524.

Rossi, R.E., D.J. Mulla, A.G. Journel, and E.H. Franz. 1991. Geostatistical tools for modeling and interpreting ecological spatial dependence. Ecol. Mono. 62:277-314.

Rousseau, J.V.D., D.M. Sylvia, and A.J. Fox. 1994. Contribution of ectomycorrhiza to the potential nutrient absorbing surface of pine. New Phytol. 128:639-644.

Sanchez, F.G. 2001. Loblolly pine needle decomposition and nutrient dynamics as affected by irrigation, fertilization, and substrate quality. For. Ecol. Manage. 152:85-96.

SAS Institute. 1999. SAS online documentation. Version 8. SAS Institute, Inc. Cary, NC.

Schultz, R.P. 1997. Loblolly Pine-The ecology and culture of Loblolly Pine (Pinus taeda L.). USDA Forest Service, USDA Agriculture Handb. No. 713. USGPO, Washington, DC.

Shaw, J.N., and E.A. Carter. 2002. Timber harvesting effects on spatial variability of southeastern US Piedmont soil properties. Soil Sci. 167:288-302.

Simard, S.W., and D.M. Durall. 2004. Mycorrhizal networks: A review of their extent function, and importance. Can. J. Bot. 82:1140-1165.

South, D.B., R.W. Rose, and K.L. McNabb. 2001. Nursery and site preparation interaction research in the United States. New For. 22:43-58.

Suarez, D.L. 1996. Beryllium, magnesium, calcium, strontium, and barium. p. 575-601. In D.L. Sparks (ed.) Methods of soil analysis. Part III. SSSA Book Series No. 5. SSSA, Madison, WI.

Thomas, G.W. 1996. Soil pH and Soil Acidity. p. 475-490. In D.L. Sparks (ed.) Methods of soil analysis. Part III. SSSA Book Series No. 5. SSSA, Madison, WI.

Trangmar, B.B., R.S. Yost, M.K. Wade, G. Uehara, and M. Sudjadi. 1987. Spatial variation of soil properties and rice yield on recently cleared land. Soil Sci. Soc. Am. J. 51:668-674.

Zinke, P.J. 1962. The pattern of influence of individual forest trees on soil properties. Ecology 43:130-133. 